\title{
Performance Evaluation of Exchange Traded Fund in The Indonesia Stock Exchange
}

\author{
Adi Cahya Stefanus ${ }^{1}$, Robiyanto ${ }^{2 *}$ \\ 1,2 Program Study Manajemen, Universitas Kristen Satya Wacana, Salatiga, Indonesia
}

\section{A R T I C L E I N F O}

Article history:

Received in revised form

25 October 2020

Accepted 30 October 2020

Available online 01

November 2020

Keywords:

Exchange Traded Fund,

Ratio
Received 11 October 2020

\section{A B S T R A C T}

This study aims to evaluate the performance of the Exchange Traded Fund (ETF) index in the Indonesia Stock Exchange by using the Treynor Ratio, Sharpe Ratio, Sortino Ratio, Jensen Alpha, Information Ratio, and Omega Ratio. This research uses a quantitative descriptive approach, and the data source to be applied in this research is secondary data, where the data to be used is the ETF listed on the IDX. The data collection technique will be carried out with a documentation study. There are 12 ETFs to be evaluated. The data used in this study are the weekly closing price and risk-free investment that is represented by the BI rate from January 2018 to December 2019. The result of this study shows that there are only two of the Exchange Traded Fund that has better performance than risk-free investment if it is calculated by using the Sharpe Ratio, Sortino Ratio, Information Ratio, and Omega Ratio. In contrast, the Treynor Ratio and Jensen Alpha show negative value or worse than risk-free investment.

Copyright () Universitas Pendidikan Ganesha. All rights reserved.

\section{Introduction}

The capital market is an investment forum for investors or people who have excess funds and are interested in investing (Alkhatib \& Harasheh, 2018; Robiyanto, 2017). Apart from having a corporate investor role, they also benefit significantly from the capital market's existence, private companies, and State-Owned Enterprises. Companies can seek additional capital from investors for operational costs (Love \& Klapper, 2003; Nasution, 2015). The capital market is also a component of a country's growth (Nasution, 2015; Wulandari, 2013).

Many people in Indonesia today still invest or save conventionally because of the lack of knowledge about the capital market. Hence, they think that saving through banking is more profitable, but the fact is that the bank interest rate received only has a small difference from the inflation that occurs. The comparison of interest rates and inflation for December 2017-2019 obtained from Bank Indonesia shown in Table 1.

Table 1. Comparison of interest rates and inflation

\begin{tabular}{ccc}
\hline Year & Interest rate (SBI) & Inflation \\
\hline 2017 & $4.25 \%$ & $3.61 \%$ \\
2018 & $6.00 \%$ & $3.13 \%$ \\
2019 & $5.00 \%$ & $2.72 \%$ \\
\hline
\end{tabular}

A solution in investing can be done through the Exchange Traded Fund (ETF). Structurally ETF returns in developing countries tend to be more generous (Mikica \& Branko, 2010; Timothy, 2013). ETFs have consistently produced higher returns outperforming market indices (Prasanna, 2012; Souza et al., 2018). ETFs are also very suitable for beginner investors because, with limited capital, they can own several companies or what is known as an index (Dervishi, 2020; Dorocáková, 2017), for example, such as LQ45, SRI-KEHATI, and IDX30. In addition, ETFs are also the same as mutual funds but are packaged like 
stocks, meaning that ETFs can be transacted during stock exchange hours and the movement of Net Asset Value (NAV) changes at any time, just like stocks.

In Indonesia, ETF was first introduced in 2007, to be precise in September, by the Indonesian capital market, which is often called the Indonesia Stock Exchange (IDX). The launch of this ETF refers to the LQ45 index and Government Securities (SUN) (Rita, 2008). The emergence of ETFs is due to meet long-term investment needs at low costs. Meanwhile, in the Asian region, several countries have profitable ETF growth, such as Japan has Nikkei (1995), Hong Kong has the Tracker Fund of Hong Kong, Singapore has the Straits Times, and China has SSE 50.

Research conducted by (Prasanna, 2012) examined India's ETF performance and impressed investors as it has an average annual growth of 37\% during the period 2006-2011. This research is also supported by (Blitz et al., 2012), who argues that the returns received from ETFs have high returns. Research on ETFs is still minimal. Therefore, an empirical study was conducted in Indonesia, hoping that ETFs can attract novice or new investors and provide investors with satisfactory returns. Also, to measure the average performance of ETFs or mutual funds using the Treynor Ratio, Sharpe Ratio, Jensen Alpha, as done by (Robiyanto, 2018; Santosa \& Sjam, 2012; Wahdah \& Hartanto, 2012). Moreover, the Sortino Ratio and Information Ratio were used by (Rohman Aziz \& Shofawati, 2019). However, it is infrequent to use the Omega Ratio; therefore, in this study, we want to add the Omega Ratio as a measure of ETF performance.

Portfolio theory is used in this study because this theory strongly supports ETF investments' performance, meaning that in one ETF transaction, the investor has got a combination of several companies (Dervishi, 2020). When one of the companies incorporated experiences problems that cause its share price to fall, other companies can be covered, which is in good condition, or the company's stock price is increasing. Portfolios that get high returns do not mean portfolios with low uncertainty (risk). However, portfolios with high returns will experience high risk conversely, if the portfolio with a low rate of return will also have a small risk level.

The application of portfolio analysis can be started by collecting information related to stocks in detail (Afonso \& Cardoso, 2019). After that, it can be ended by making conclusions related to the portfolio as a whole. Sources of information that can be accessed for this portfolio analysis include the past performance of a company, past stock prices, and conducting stock analysis with a positive view of stock performance in the future. When past company performance is used as input, the output of portfolio analysis has performed well.

ETF was first issued on the Toronto, Canada stock exchange in 1990, after which it expanded to the northern part of America, namely the United States, in 1993. In 1999 it began to spread in parts of Europe and Asia. In 2007, ETFs began to enter Indonesia because they were predicted to attract investors and have promising prospects due to their relatively low costs. ETF can be interpreted as mutual funds but is traded on the exchange from 09.30-16.00. These purchases are more manageable than mutual funds, where if the purchase is past 13.00, it will be recorded in the next day's purchase. For sales, ETFs are also superior to regular mutual funds because they only need $t+2$ or two days from the sale, and the funds can be received by investors, while mutual funds require a maximum of $t+7$.

This research aims to know ETFs' performance on the Indonesia Stock Exchange (IDX) and provide information on ETFs' development to attract young or novice investors. Hopefully, this research can help investors in making decisions and investing when experiencing unfavorable financial conditions.

\section{Methods}

This research uses a quantitative descriptive approach, and the data source to be applied in this research is secondary data, where the data to be used is the ETF listed on the IDX. The data collection technique will be carried out with a documentation study, which means that it will be carried out by collecting, reading, and identifying reports from each ETF that will be accessed through the IDX website. (www.idx.co.id).

The population of this study is stock ETFs listed on the IDX in 2018-2019. The ETF research was conducted because ETF research in Indonesia is still minimal, which sparked evaluating ETF performance. This study's sampling mechanism used purposive sampling with the intended ETF criteria to be listed on the IDX from the beginning of January 2018 to December 2019. The data to be used is weekly data. The list of ETFs' that meet the criteria from 2018-2019 shown in Table 2. 
Table 2. List of ETFs that meet the criteria from 2018-2019

\begin{tabular}{|c|c|c|c|c|}
\hline No & Code & ETF Name & Listing Date & Investment Manager \\
\hline 1 & R-LQ45X & Reksa dana premier ETF LQ45 & $18 / 12 / 2007$ & $\begin{array}{l}\text { PT Indo Premier Investment } \\
\text { Management }\end{array}$ \\
\hline 2 & XIIT & Reksa dana premier ETF IDX30 & $30 / 10 / 2012$ & $\begin{array}{l}\text { PT Indo Premier Investment } \\
\text { Management }\end{array}$ \\
\hline 3 & XIIC & $\begin{array}{l}\text { Reksa dana premier ETF } \\
\text { Indonesia Consumer }\end{array}$ & $30 / 04 / 2013$ & $\begin{array}{l}\text { PT Indo Premier Investment } \\
\text { Management }\end{array}$ \\
\hline 4 & XIJI & $\begin{array}{l}\text { Reksa dana premier Syariah } \\
\text { ETF JII }\end{array}$ & $30 / 04 / 2013$ & $\begin{array}{l}\text { PT Indo Premier Investment } \\
\text { Management }\end{array}$ \\
\hline 5 & XISI & $\begin{array}{l}\text { Reksa dana premier ETF } \\
\text { SMINFRA18 }\end{array}$ & 06/03/2014 & $\begin{array}{l}\text { PT Indo Premier Investment } \\
\text { Management }\end{array}$ \\
\hline 6 & XISR & $\begin{array}{l}\text { Reksa dana premier ETF SRI- } \\
\text { KEHATI }\end{array}$ & $26 / 09 / 2014$ & $\begin{array}{l}\text { PT Indo Premier Investment } \\
\text { Management }\end{array}$ \\
\hline 7 & XIIF & $\begin{array}{l}\text { Reksa dana premier ETF } \\
\text { Indonesia financial }\end{array}$ & $19 / 11 / 2014$ & $\begin{array}{l}\text { PT Indo Premier Investment } \\
\text { Management }\end{array}$ \\
\hline 8 & XISC & $\begin{array}{l}\text { Reksa dana premier ETF } \\
\text { Indonesia state-owned } \\
\text { companies }\end{array}$ & $01 / 10 / 2015$ & $\begin{array}{l}\text { PT Indo Premier Investment } \\
\text { Management }\end{array}$ \\
\hline 9 & XPLQ & $\begin{array}{l}\text { Reksa dana pinnacle enhanced } \\
\text { liquid ETF }\end{array}$ & $15 / 08 / 2016$ & PT Pinnacle Persada Investama \\
\hline 10 & XPDV & $\begin{array}{l}\text { Reksa dana pinnacle high core } \\
\text { dividend ETF }\end{array}$ & $09 / 06 / 2017$ & PT Pinnacle Persada Investama \\
\hline 11 & XPLC & $\begin{array}{l}\text { Reksa dana pinnacle Indonesia } \\
\text { large-cap ETF }\end{array}$ & $14 / 06 / 2017$ & PT Pinnacle Persada Investama \\
\hline 12 & XPES & $\begin{array}{l}\text { Reksa dana Syariah pinnacle } \\
\text { enhanced sharia ETF }\end{array}$ & $12 / 10 / 2017$ & PT Pinnacle Persada Investama \\
\hline
\end{tabular}

There are several analytical tools in measuring ETF performance that can help investor measure portfolio performance in evaluating ETFs, namely Trenor Ratio, Shape Ratio, Jensen Alpha, Sortino Ratio, Information Ratio, and Omega Ratio.

A portfolio performance method by considering market risk (Treynor, 1965). This is also supported by (Wahdah \& Hartanto, 2012) research, which stated that the Treynor measurement method must pay attention to market fluctuations. If the Treynor ratio is greater than the market Treynor, then it has good performance. This method is based on managed ETF assets, which are a collection of liquid assets and are different from assets managed by the company; therefore, investment managers can freely determine their investment policies. In this condition, (Treynor, 1965) formulate a measurement that considers the level of volatility. This method is known as the Treynor Ratio (Treynor, 1965).

Besides the Treynor Ratio, (Sharpe, 1966) formulates that the Sharpe Ratio can also measure mutual funds / ETFs' performance. According to (Wahdah \& Hartanto, 2012), The Sharpe Ratio method aims to see how much investment return can be in each unit of risk taken, and the greater the value of the Sharpe Ratio from the market, the better. Sharpe Ratio is also widely implemented by practitioners in the financial sector to measure ETFs and mutual funds (Low \& Chin, 2013).

Jensen Alpha is developed by Jensen (1968), which defines that this model is used to monitor mutual fund managers' risk performance on a risk-adjusted basis. Jensen Alpha is used to measure the fund manager's performance against investors' returns by adjusting the funds' correlation. It can also be concluded that Jensen Alpha tries to explain whether an investment has performed well or poorly when the market is perfect or equal to zero. Alpha positive or higher means that the mutual fund or ETF is performing well. This design can also measure the average actual return on the portfolio's theoretical return utilizing the Capital Asset Pricing Model (CAPM).

The Sortino Ratio is a modification of the Sharpe Ratio that distinguishes between general volatility and dangerous volatility by calculating the standard deviation of a negative rate of return or what is known as the downside deviation. (Rollinger \& Hoffman, 2013; Sortino \& Price, 1994),

Information Ratio is a ratio that can measure mutual fund consistency to generate returns and is different from the benchmark (comparative value), which is used as a reference, namely market value. According to (Hartono, 2010), in the research, (Rohman Aziz \& Shofawati, 2019) said that a mutual fund is not negative or higher than the market information ratio. The mutual fund will perform well. 
The Omega ratio is the ratio of cumulative probability to which a lower and upper threshold is determined. This function has many mathematical properties that can be interpreted in financial terms. For example, if the average return is the threshold, then the Omega value will be one of the greater the threshold level, the smaller the omega value.

\section{Results and Discussions}

\section{Descriptive statistics}

The descriptive statistics of ETF prices in this study can be observed in Table 3. All the ETF prices studied involved 104 weeks of observation.

Table 3. Descriptive statistics

\begin{tabular}{ccccccc}
\hline No & ETF & Min & Max & Mean & Standard Deviation & N \\
\hline 2 & XIIC & -0.0858 & 0.1096 & -0.0006 & 0.0223 & 104 \\
3 & XIIT & -0.0697 & 0.2233 & 0.0034 & 0.0312 & 104 \\
4 & XIIF & -0.0890 & 0.0612 & -0.0010 & 0.0274 & 104 \\
5 & XIJI & -0.0614 & 0.0555 & -0.0004 & 0.0230 & 104 \\
6 & XISC & -0.1315 & 0.0667 & -0.0004 & 0.0297 & 104 \\
7 & XISI & -0.1091 & 0.0765 & -0.0004 & 0.0284 & 104 \\
8 & XISR & -0.0786 & 0.0636 & 0.0006 & 0.0237 & 104 \\
9 & XPDV & -0.0870 & 0.0884 & -0.0008 & 0.0250 & 104 \\
10 & XPES & -0.0543 & 0.1232 & -0.0010 & 0.0213 & 104 \\
11 & XPLC & -0.0929 & 0.0588 & -0.0013 & 0.0189 & 104 \\
12 & XPLQ & -0.0829 & 0.0721 & -0.0007 & 0.0213 & 104 \\
\hline
\end{tabular}

It can be seen in Table 3 that the lowest ETF return is the XISC ETF with a return of -0.1315 , while the highest return is the XIIT ETF of 0.2233. 3 ETFs have a positive average return value, namely the RLQ45X, XIIT, and XISR ETFs with returns of 0.0029, 0.0034, and 0.0006, respectively.

Table 4. ETF performance on the Indonesia Stock Exchange

\begin{tabular}{ccccccc}
\hline ETF & Treynor & Sharpe & Jensen Alpha & Sortino & Information Ratio & Omega \\
\hline XIIC & -0.0214 & -0.8057 & -0.0094 & 0.0060 & -0.0348 & 0.1727 \\
XIIF & -0.0099 & -0.6001 & -0.0169 & 0.0044 & 0.0157 & 0.3093 \\
XIIT & -0.3771 & -0.4390 & 0.1456 & 0.0023 & 0.1284 & 0.3775 \\
XIJI & -0.0139 & -0.7732 & -0.0135 & 0.0054 & -0.0213 & 0.1994 \\
XISC & -0.0180 & -0.6182 & -0.0106 & 0.0045 & -0.0185 & 0.2764 \\
XISI & -0.0145 & -0.6458 & -0.0131 & 0.0047 & -0.0215 & 0.2737 \\
XISR & -0.0119 & -0.7078 & -0.0138 & 0.0050 & 0.0234 & 0.2280 \\
XPDV & -0.0650 & -0.7378 & -0.0037 & 0.0054 & -0.0380 & 0.2126 \\
XPES & -0.0483 & -0.8601 & -0.0051 & 0.0064 & -0.0571 & 0.1613 \\
XPLC & -0.0434 & -0.9560 & -0.0059 & 0.0064 & -0.0740 & 0.1054 \\
XPLQ & -0.0302 & -0.8447 & -0.0070 & 0.0059 & -0.0419 & 0.1800 \\
\hline
\end{tabular}

\section{Treynor Ratio}

The Treynor ratio is used to evaluate the performance of ETFs on the Indonesia Stock Exchange, as presented in Table 4. It can be seen that none of the ETF performance, as measured by Treynor, has a positive value. The significance of the Treynor Ratio for the negative ETF shows that the performance of the ETF in the observation period is not better than that of a risk-free investment instrument. The significance of Treynor is positive; it shows that ETF performance is better than risk-free investment.

The best performance when compared to other ETFs is XIIF, with a Treynor value of -0.0099 . However, the performance of XIIF ETF in the observation period is no better than risk-free investment instruments. The ETF with the worst performance, when measured using Treynor, is the XIIT ETF, with a value of -0.3771 . 


\section{Sharpe Ratio}

Treynor uses the Sharpe Ratio to assess ETFs' performance on the Indonesia Stock Exchange, as illustrated in Table 4. It can be seen that there are no ETFs that are measured by the Sharpe Ratio to have a positive value. As measured by Sharpe, the ETF performance is negative, indicating that the ETF performance during the observation period is not better than the risk-free level. So, in investing, investors should not invest in ETFs with negative Sharpe values. It is better to invest in risk-free investment instruments. The Sharpe value of the XIIT ETF is the highest compared to other ETFs at -0.4390 . Meanwhile, the worst ETF performance in the observation period was XPLC ETF, with a value of 0.9560 .

\section{Jensen Alpha}

Using Jensen Alpha to assess ETFs' performance on the Indonesia Stock Exchange, as seen in Table 4. It can be observed that only XIIT ETF has a positive value of 0.1466. Thus, only XIIT ETF has better performance than risk-free investment instruments. Besides XIIT ETF, it shows that the performance of other ETFs is no better than market performance. At the same time, the lowest ETF is XIIF with Jensen Alpha -0.0169.

\section{Sortino Ratio}

The Sortino Ratio is a modification of the Sharpe Ratio in which the downside deviation replaces the standard deviation (Rollinger \& Hoffman, 2013). The higher the Sortino value indicates that, the better the ETF's performance, and vice versa. Based on the results of calculations using the Sortino Ratio presented in Table 4. All ETFs have better performance than risk-free investments. However, the best ones are XPLC and XPES, with a value of 0.0064 , and the one with the lowest value is 0.0023 , namely XIIT.

\section{Information Ratio}

By applying the Information Ratio to assess the performance of stock ETFs on the Indonesia Stock Exchange, it can be seen that only 3 ETFs are measured by Information Ratio, namely XIIT with a value of 0.1284, R-LQ45X with a value of 0.1225 , and XISR with a value of 0,0234 . This shows that the XIIT, RLQ45X, and XISR ETFs have a good performance when compared to risk-free investments and other ETFs on the IDX.

ETF performance, as measured by Sharpe, is negative, indicating that the ETF performance during the observation period is not better than the risk-free investment level. So, in investing, investors should not invest in ETFs with negative information values. It is better to invest in risk-free instruments.

\section{Omega Ratio}

The Omega ratio is a ratio used to calculate the average ratio between profits and losses received by investors. Investors' probability of again that investors will receive is the same as the possibility of loss that investors will receive. The greater the profit, the greater the risk faced. The calculation of Omega ETF XIIT has the most significant probability of profit and loss, which is 0.3020 . If investors invest in XIIT ETF, the expected return will be $30.2 \%$.

Meanwhile, XPLC ETF has the smallest value of expected return, which is 0.1054 or $10 \%$, but the risk of loss received is smaller when compared to other ETFs. In measuring portfolio performance, you cannot only use the Omega Ratio because the Omega Ratio can only measure the average probability between the gains and losses that will be received. To determine whether or not it is appropriate to invest in ETFs, other ratios can be used.

\section{Conclusion}

The research findings are based on calculations using five ratios. They consist of the Treynor Ratio, Sharpe Ratio, Jensen Alpha, Information Ratio, Sortino Ratio, and Omega Ratio to assess almost all ETFs listed on the IDX to perform less well than risk-free investment instruments. Thus, investors should choose the XIIT and R-LQ45X ETFs for several years later as long as these ETFs are still producing excellent and consistent performance. Investors should also avoid some stock ETFs, especially in the mining and oil and gas sectors, for the next few periods. Nevertheless, if there are some improvements in this sector, namely the rise in commodity prices, investors can consider this sector as their investment instrument. Since there is no guarantee that past performance can reflect future performance, investors should re-evaluate ETF performance periodically. 


\section{References}

Afonso, A., \& Cardoso, P. (2019). Exchange-traded funds as an alternative investment option. Notas Económicas, 48(1). https://doi.org/10.14195/2183-203X_48_1

Alkhatib, A., \& Harasheh, M. (2018). Performance of Exchange Traded Funds during the Brexit Referendum: An Event Study. International Journal of Financial Studies, 6(3), 64. https://doi.org/10.3390/ijfs6030064

Blitz, D., Huij, J., \& Swinkels, L. (2012). Exchange-Traded Funds. European Financial Management, 18(4), 649-662. https://doi.org/10.1111/j.1468-036X.2010.00550.x

Dervishi, B. (2020). Investments and portfolio structure of private pension and insurance companies in North Macedonia. International Journal of Research In Business and Social Science, 9(5), 227-234. https://doi.org/10.20525/ijrbs.v9i5.860

Dorocáková, M. (2017). Comparison of ETF's performance related to the tracking error. Journal of International Studies, 10(4), https: //doi.org/10.14254/2071-8330.2017/10-4/12.

Hartono, J. (2010). Teori Portofolio dan Analisis Investasi (Edisi Sepuluh). In Yogyakarta: BPFE.

Jensen, M. C. (1968). the Performance of Mutual Funds in the Period 1945-1964. The Journal of Finance, 23(2), 389-416. https://doi.org/10.1111/j.1540-6261.1968.tb00815.x

Love, I., \& Klapper, L. F. (2003). Corporate Governance, Investor protection, and Performance in Emerging Markets. https://doi.org/10.1596/1813-9450-2818

Low, S. W., \& Chin, Y. B. (2013). Refinements to the Sharpe Ratio - Evidence from Malaysian Equity Funds. Global Economic Review, 42(1), 72-97. https: //doi.org/10.1080/1226508X.2013.769818

Mikica, D., \& Branko, U. (2010). Exchange-traded funds of the eurozone sovereign debt. Ekonomski Anali, 55(187), 31-60. https://doi.org/10.2298/EKA1087031D

Nasution, Y. S. J. (2015). Peranan Pasar Modal Dalam Perekonomian Negara. HUMAN FALAH: Jurnal Ekonomi Dan Bisnis Islam, 2(1), 95-112.

Prasanna, K. (2012). Performance of Exchange-Traded Funds in India. International Journal of Business and Management, 7(23), 122-143. https://doi.org/10.5539/ijbm.v7n23p122

Rita, M. R. (2008). EXCHANGE TRADED FUND (ETF): Inovasi dalam Dunia Industri Reksa Dana di Indonesia. Jurnal Ekonomi Dan Bisnis, 1, 91-105.

Robiyanto, R. (2017). Performance Evaluation and Risk Aversion Rate for Several Stock Indices in Indonesia Stock Exchange. Jurnal Manajemen Dan Kewirausahaan, 19(1), 60-64. https://doi.org/10.9744/jmk.19.1.60-64

Robiyanto, R. (2018). Performance Evaluation of Stock Price Indexes in the Indonesia Stock Exchange. International Research Journal of Business Studies, 10(3), 173-182. https://doi.org/10.21632/irjbs.10.3.173-182

Rohman Aziz, N., \& Shofawati, A. (2019). Pengukuran Metode Rasio Informasi, Rasio Sortino Dan Roy Safety First Ratio Pada Kinerja Reksadana Saham Syariah Periode 2015-2017. Jurnal Ekonomi Syariah Teori Dan Terapan, 6(8), 1644-1659.

Rollinger, T. N., \& Hoffman, S. T. (2013). Sortino : A 'Sharper' Ratio.

Santosa, M., \& Sjam, A. (2012). Penilaian Kinerja Produk Reksadana Dengan Menggunakan Metode Perhitungan Jensen Alpha, Sharpe Ratio, Treynor Ratio, M2, Dan Information Ratio. Jurnal Manajemen Maranatha, 12(1), 113086. https://doi.org/10.28932/jmm.v12i1.174

Sharpe, W. F. (1966). Mutual Fund Performance. CHICAGO JOURNALS, 39(1), 119-138. https://doi.org/10.5840/bemag199812115

Sortino, F. A., \& Price, L. N. (1994). Performance Measurement in a Downside Risk Framework. The Journal of Investing. https://doi.org/10.3905/joi.3.3.59

Souza, G. S., Penedo, A. S. T., \& Pereira, V. S. (2018). Exchange Traded Funds - ETF e fundos mútuos de índice brasileiros: uma comparação de performance e aderência. Estudos Do CEPE, 1(1), 04-22. https://doi.org/10.17058/cepe.v0i0.11530 
Timothy, P. (2013). An examination of the relationship between the Economic Freedom Index value and the matching country specific exchange traded fund return. Managerial Finance, 39(7), 677-690. https://doi.org/10.1108/03074351311323464

Treynor, J. L. (1965). How to rate management investment funds. Harvard Business Review. https://doi.org/10.1002/9781119196679.ch10

Wahdah, R., \& Hartanto, J. (2012). Analisis Pengukuran Kinerja Reksa Dana Saham di Indonesia. Jurnal Manajemen Dan Akuntansi, 13(April), 35-44.

Wulandari, P. A. (2013). Evaluasi Kinerja Reksadana Saham Indonesia. Jurnal Intekna, 3, 227-234. 